\title{
The Influence of Organizational Culture, Competency and Teacher's Certification toward Teacher's Performance
}

\author{
Hatemu $^{1}$, Bukman Lian $^{2}$, Yessi Fitriani ${ }^{3}$ \\ ${ }^{1}$ SD Negeri 7 Pulau Rimau, \\ ${ }^{2,3}$ Universitas PGRI Palembang \\ $(c)$ EY
}

\begin{abstract}
This study aimed at determining the effect of organizational culture, competency and certification toward teacher's performance. This research belongs to quantitative ex post facto. The sample in this study was all teachers in SD Negeri Rayon 2 Pulau Rimau, which consisted of 28 teachers. Data were collected using questionnaire. Data were analysed using descriptive analysis and multiple regressions. The results of this study showed that 1) there is significant influence of organizational culture on teacher's performance; 2) there is significant influence of competency on the teacher's performance; 3) there is significant influence of teacher's certification on the teacher's performance; 4) there is significant influence jointly organizational culture, competency and teacher's certification on the teacher's performance.
\end{abstract}

Keywords - Organizational Culture, Competency, Certification, Teacher's Performance

\section{INTRODUCTION}

Teachers are one of the school's resources required to have high performance. Teacher's performance in schools has an important role in achieving school goals (Salwa et al, 2019; Andriani et al, 2018; Renata et al, 2018; Murtiningsih et al, 2019). Therefore, teachers are required to have high performance and must be able to serve optimally. Because the teacher is positioned as the frontline in the implementation of the learning process. In other words, the teacher holds a very strategic position to create competent and qualified graduates to meet the needs of professional human resources (Irmayani et al, 2018; Tobari et al, 2018).

According to Prawirosentono (2011) performance is the work that can be achieved by a person or group of people in an organization, in accordance with their respective authorities and responsibilities to achieve the objectives of the organization concerned legally, not violating the law and in accordance with norms and ethics. In the broad context Robbins (2012) states that improving employee performance will bring progress for the company to survive in an unstable business environment competition. Therefore to improve employee performance are the most serious management challenges because success in achieving goals and survival of the company depends on the quality of the performance of the human resources that are in it (Irmayani et al, 2018; Tobari et al, 2018; Fathurrochman et al, 2019).

Teacher's performance is a very important thing in to achieve the goals of school institutions, because performance is a real behavior that is displayed by everyone as work performance produced by teachers in accordance with their role in educational institutions. The teacher is one of the human resources in the school. Various attempts were made to achieve good performance. There are several factors, both internal and external that can affect teacher's performance. These factors include organizational work culture, competencies and teacher certification. 
An employee performs well, not only determined by individual internal factors (motivation, perception, mastery of substance and technical skills), but is also strongly influenced by external factors, especially those from the organization where he works, such as the accuracy of the assignment, leadership attitude, organizational work systems and opportunities to do work optimally. One of the external factors is the work culture within an organization in this context is the work culture that is built must be based on merit. The higher desire to pursue achievement, the higher desire to overcome difficulties in carrying out tasks and job responsibilities. Locke (2011) states that the level of difficulty of high goals produces high performance or the level of difficulty of low goals produces low performance of individuals who have high performance. However, the high level of difficulty of the goals produces frustration with individuals who have low performance.

Based on the opinion above, the culture of achievement built in educational organizations greatly influences teacher's commitment and teacher's commitment can have a positive impact on performance. Teacher's commitment has been considered an important factor in influencing effectiveness. Park, (2015) states that teacher's commitment has gradually been recognized as the most determining factor in the effectiveness of a school. Teacher's commitment is also an important element for school success related to teacher's performance.

Teacher's competency is a picture of the qualitative nature and behavior of teachers that seem very meaningful. Behavior here refers not only to real behavior, but also includes things that are not visible. Jackson (2011) suggested that the ability is rational behavior to achieve the required goals in accordance with the expected conditions. He said to be rational because it has a certain direction or purpose. Barlow (2011) argues that the ability of a teacher is to carry out their responsibilities properly. Thus, the ability of teachers is an internal capacity possessed by teachers in carrying out professional tasks. The task of the teacher profession can be measured by how far the teacher drives the process of implementing effective and efficient learning.

As professionals, there are at least two competencies that must be possessed by teachers 1) professional competencies related to the 3 skills of designing, implementing and evaluating assignments; 2) personal competency which includes ethics, morals, devotion, and social and spiritual abilities. Professional teachers are not only required to master the fields of science, teaching materials, learning methods, motivate students, have high skills and broad insights into the world of education, but also must have a deep understanding of human nature, this nature will underlie mindset and culture teacher work, and loyalty to the education profession (Saniyah, 2008).

Based on Regulation of Minister Education Number $16 / 2007$, it is emphasized that teachers need to have certain minimum competency standards in carrying out their teaching assignments. Competency standards are expected to be the basis for the realization of teacher's performance as well as an effort to improve the quality of student education outcomes (Khasanah et al, 2019; Sarina et al, 2019). In line with this there is an opinion about the development of teacher's performance not only teaching in the classroom, but every development experienced by student teachers must know and understand it, because learning will run effectively if the teacher has the ability to map the position and potential of students (Wandasari et al, 2019; Apriana et al, 2019).

Performance is an activity carried out by each individual in relation to achieving the planned objectives. In this regard there are several definitions of performance. Mulyasa (2010) states that performance is output drive from processes, human or otherwise. Performance is the result or output of a process. It was further said that performance can be interpreted as work performance, work achievement, work results. Performance is a concept that is universal which is the operational effectiveness of an organization, parts of the organization, and its employees based on predetermined standards and criteria. Because the organization is basically run by humans, the actual performance is human behavior in carrying out its role in an organization to meet the standards of behavior that have been set in order to produce the desired actions and results.

Teacher's performance appraisal has benefits for a school because this assessment will provide the level of achievement of the standard, size or criteria set by the school. So that the weaknesses contained in a teacher can be overcome and will provide feedback to the teacher. According to Mangkupawira (2014), the benefits of employee performance appraisal are 1) performance improvement; 2) compensation adjustment; 3) decision on designation; 4) training and development needs; 5) career planning and development; 6) efficient staffing process; 7) inaccuracy of information; 8) work design errors; 9) equal employment opportunities; 10) external challenges; 11) feedback on Human Resource For schools, the results of performance appraisal are very important in making various 
decisions, such as identifying the needs of school programs, acceptance, selection, introduction, placement, promotion, reward systems and other aspects of the overall process of developing human resources as a whole (Mulyasa, 2010).

Based on the description above, it can be seen that performance appraisal is important to be carried out by a school to improve the performance of the teacher itself and for the school in terms of rearranging plans or new strategies to achieve national education goals (Lian et al, 2018). Assessments made can be input for teachers in improving their performance. In addition, teacher's performance appraisals help teachers to know their tasks better so that teachers can carry out learning as effectively as possible for the progress of students and the progress of the teacher himself towards a professional teacher. Teacher's performance assessment is not intended to criticize and find fault, but rather as an encouragement for teachers in constructive understanding in order to develop themselves to be more professional and eventually will improve the quality of student education. This requires a change in mindset and behavior and the teacher's willingness to reflect on an ongoing basis.

Organization is a formal union system of two or more people who work together to achieve organizational goals (Hasibuan, 2012). Organization is a social unity of a group of people, who interact with each other according to a pattern, so that members of the organization have their respective functions and duties. The organization, as a whole, has certain goals and has clear boundaries, so that it can be strictly separated from its environment. There are so many definitions of culture that in essence do not differ greatly from one expert to another. Organizational culture as a system of roles, activities and processes involves several people as task implementers, designed to carry out shared goals (Chatab, 2012). Understanding organizational culture explains the corporate culture hierarchy as follows 1) the basic assumptions is the deepest level, and is in the subconscious; 2) value is the next level of concern about what the organization should be; 3 ) norms tell the members what should and should not do under certain circumstances; 4) artifact is a concrete form such as systems, procedures, regulations, structure and physical aspects of the organization, (Chatab, 2012).

Each organizational culture shows certain characteristics on an organizational scale that are homogeneous. All of these cultures must be understood and integrated, if the organization wants to work effectively. The more members accept the core values and the greater their commitment to those values, the stronger the culture will have a great influence on the behavior of its members because the level of togetherness and intensity will create a climate of high behavior control (Robbins, 2012).

Ministry of National Education (2014) formulates the definition of competency as knowledge, skills and basic values that are reflected in the habits of thinking and acting. Competency is the ability, skills possessed by a person regarding his duties, positions and profession. Competency is complex and constitutes a unified whole that illustrates the potential, knowledge, skills, attitudes and values of a person associated with a particular profession with regard to parts that can be actualized or realized in the form of actions or performance to carry out the profession Hamalik ( 2013).

From the results of observations by researchers in elementary schools Pulau Rimau. The researcher considers that some elementary schools in Pulau Rimau have not been able to manage human resources that pay attention to organizational culture that is able to provide motivation to teachers such as research culture, writing culture, and achievement culture which will certainly affect teacher's performance both directly and indirectly will affect also on the quality and productivity of educational institutions. Meanwhile, on the other hand, the government has provided financial compensation to teacher that has been given by the government to improve teacher welfare, one of which is through teacher certification. But the facts show teacher's performance is still not optimal. It was found that teachers did not make Learning Implementation Plans, ignored the completeness of teacher administration, gave assignments without face-to-face processes, the use of monotonous models and methods, and evaluation of learning that was not optimal. Then based on the results of the 2017 performance report, it was stated that the performance of teachers in the Banyuwangi Regency was still low. This is evidenced by the results of Jakparudin (2018) which states that only $47 \%$ of the number of teachers who received certification had low performance and that originally only $19 \%$ of the number of teachers who had been certified showed low performance (Disdikpora, 2017). Whereas teachers who have received certification should have good teacher certification worth the financial compensation that has been given. From the above background, the we feel it is necessary to further examine whether competency, certification and organizational culture effect the teacher's performance. 


\section{METHODS}

This research was carried out in state elementary schools in Pulau Rimau. Elementary schools in Pulau Rimau were selected by us because the school has adequate criteria for research. The research time was carried out on March 1, 2019 to December 1, 2019. This research is quantitative, according to Musfiqon, (2012) quantitative focused on the study of objective phenomena to be studied quantitatively. Research data collection is done quantitatively. This research used the partial correlation method. Partial correlation is used for analysis or hypothesis testing if the researcher intends to know the effect or relationship of the independent variable with the dependent variable, where one of the independent variables is controlled. The design of this research uses the ex post facto that aims to investigate the events that have occurred and then trace back to find out the factors that caused the event (Sugiyono, 2012).

Data collection techniques in this study using a questionnaire. According to Widoyoko (2012), a questionnaire is a method of data collection carried out by giving a set of statements or written statements to respondents to respond in accordance with user requests. The data scale used is a Likert scale. If there are difficulties in understanding the questionnaire, respondents can immediately ask the researcher.

The validity used in this study is internal validity. According to Arikunto, (2010) this validity is achieved when there is compatibility between the instruments as a whole. An instrument can be said valid if the instrument measures what you want measured. Validity is a parameter that indicates the level of validity of an instrument. Testing the validity of the instrument is by determining the price of the correlation between the parts of the measuring instrument as a whole by correlating each measuring instrument with a total score which is the sum of each item score. The activity of calculating the validity of a measuring instrument must have a high validity. The validity instrument in this study was measured using the Product Moment formula from Pearson.

Data collection techniques in this study using a questionnaire. According to Widoyoko (2012), a questionnaire is a method of data collection carried out by giving a set of statements or written statements to respondents to response in accordance with user requests. The data scale used is a Likert scale. If there are difficulties in understanding the questionnaire, respondents can immediately ask the us. This questionnaire is used to get data about the research variables. Requirements for analyzing research data is testing of normality and homogeneity. This is done as a prerequisite for using product moment correlation analysis and multiple correlation because product moment correlation is a parametric statistic.

\section{RESUlts AND Discussion}

This research is a quantitative study with a partial correlation method, partial correlation is used for analysis or hypothesis testing if the researcher intends to know the effect of the independent variable with the dependent variable, where one of the independent variables is controlled (Sugiyono, 2012). The variables examined in this study are organizational culture (variable $\mathrm{X}_{1}$ ), competency (variable $\mathrm{X}_{2}$ ), teacher certification (variable $\mathrm{X}_{3}$ ) and teacher's performance (variable $\mathrm{Y}$ ). Then this research was carried out in Elementary Schools in Pulau Rimau. With the number of samples in this study were 28 teachers who have been certified.

Before distributing questionnaires to respondents, the researchers first made initial observations to determine what variables were the object of study. After that the researchers collected material in the form of school data and prior research studies as a research reference for subsequent stages. Then the researchers conducted a research tool compilation, a questionnaire as a data collection tool. The questionnaire that became a research tool was then validated in two stages. The first stage is to validate the questionnaire to the experts who have been selected and considered by researchers to have the capacity to validate the questionnaire. The experts who validated this research tool consisted of three validators. After a revision was made on the recommendations of the experts mentioned above. Then the second stage of validation is to test 10 respondents taken from a portion of the research sample. After the validation and reliability test is done then sorting the question items that are declared valid based on trials that have been done. To simplify the analysis process, the data analysis process in this study uses the SPSS 22.00 for Windows program.

After the questionnaire was declared valid and feasible to be used as a data collection tool, then the researchers spread the questionnaire to all research respondents, namely the head of the school in the District of Pulau Rimau, Palembang as many as 28 respondents. The distribution of questionnaires to respondents (samples) of the research was conducted in November 2019 to December 2019. After distributing the questionnaire the researchers then performed statistical calculations to find out the results of the statistical description of the research data and hypothesis 
testing to find out the results of the hypotheses in this study. Before testing the hypothesis on each of the research variables. the researcher will first display a description of the data for each variable in this study. The objective of the researcher to display the description of this data is to categorize each of the research variables into the categories determined by the researchers, namely the very high, high, high enough, low and very low categories. The description of the data in this study is as follows.

\section{Cultural Organizations of Elementary Schools in Pulau Rimau}

In this variable, there are 12 indicators to determine the organizational culture of elementary schools IN Pulau
Rimau 1) Building good cooperation; 2) Encourage the achievement of optimal work, 3) Have the desire to achieve the highest performance; 4) Understand the rules that apply in schools; 5) Has integrity in carrying out the applicable rules; 6) Have loyalty to school institutions; 7) Decisive in giving and carrying out sanctions; 8) Providing good service; 8) Has high responsibility for work; 9) Having confidence; 10) Have a high morale; 11) Leaders give high trust to subordinates; 12) Subordinates try to carry out the duties and responsibilities given to the maximum. All indicators are included in 12 questions. The results of the descriptive analysis of organizational culture variables in elementary schools in Pulau Rimau are as follows.

Table 1. Variables of Elementary School Organizational Culture in Pulau Rimau

\begin{tabular}{lll}
\hline $\mathrm{N}$ & Valid & 28 \\
& Missing & 0 \\
\hline Mean & & 49.0714 \\
Median & 48.0000 \\
Std. Deviation & 3.44188 \\
Variance & 11.847 \\
Minimum & 43.00 \\
Maximum & 55.00 \\
\hline
\end{tabular}

Source: Results of Data Processing Using SPSS

From the above table, it can be explained that the mean value is 49 median values of 48 , standard deviation values of 3.4 minimum values of 43 and maximum values of 55 . From the results of the frequency distribution analysis above, it can be analyzed the criteria of the research respondents with very high, high, high enough, and less categories. The results of the criteria for organizational culture variable variables in elementary schools in Pulau Rimau are as follows.

Table 2. Percentage of Primary School Organizational Culture in Pulau Rimau

\begin{tabular}{llllc}
\hline Number & Norm & Frequency & \% & Category \\
\hline 1 & $\geq 54$ & 3 & $10,7 \%$ & Very Good \\
2 & $51 \mathrm{~s} / \mathrm{d}<54$ & 8 & $28,6 \%$ & Good \\
3 & $47 \mathrm{~s} / \mathrm{d}>51$ & 9 & $32,1 \%$ & Enough \\
4 & $44 \mathrm{~s} / \mathrm{d}<47$ & 7 & $25 \%$ & Less \\
5 & $<44$ & 1 & $3,6 \%$ & Very Less \\
\hline
\end{tabular}

Based on the results of the analysis of the categories above, it can be pointed out that the culture of the organization with a very good category is 0 or $0 \%$, the good category is 32 or $47.76 \%$, the category is quite good at 14 or $20,89 \%$, the less category is 18 or $26,86 \%$, and very less in the category of 3 or $4.47 \%$. The results of the analysis show that when viewed from the highest score, the organizational culture of elementary schools throughout the Pulau Rimau is included in the quite good category. The percentage of organizational culture variable categories in elementary schools in Pulau Rimau can be seen also in the following figure. 


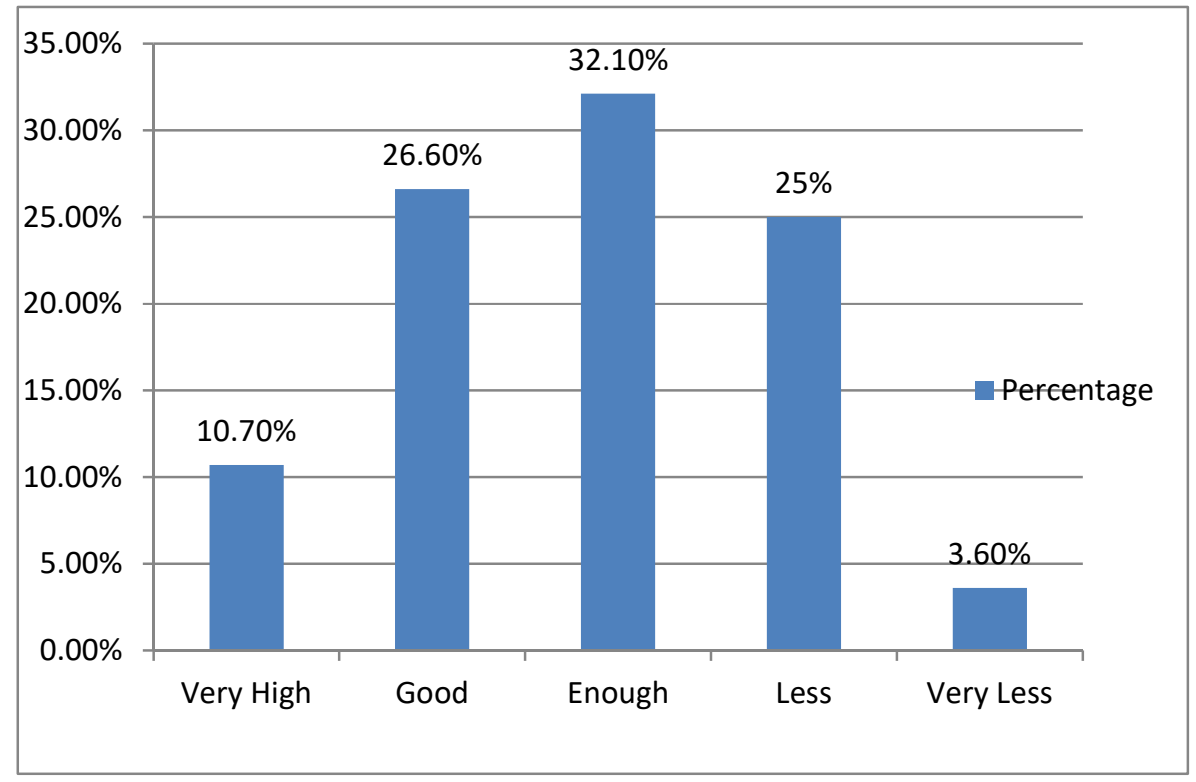

Figure 1: Organizational Culture Percentage

In this variable, there are 4 indicators to determine the competency of elementary school teachers in Pulau Rimau, namely: 1) Professional competency; 2) Personality competency; 3) social competency; 4) Pedagogic comet. All indicators are included in 13 questions. The results of the descriptive analysis of the variables of elementary school teacher competency in Pulau Rimau are as follows.

Table 3. Descriptive Variable Competency of Elementary School Teachers in Pulau Rimau

\begin{tabular}{lll}
\hline$N$ & Valid & 28 \\
& Missing & 0 \\
\hline Mean & & 48.9286 \\
Median & 48.0000 \\
Std. Deviation & 3.21948 \\
Variance & 10.365 \\
Minimum & 44.00 \\
Maximum & 56.00 \\
\hline
\end{tabular}

Source: Results of Data Processing Using SPSS

From the table above, it can be stated that the mean value is 48.9 , the median value is 48 , the standard deviation value is 3.2 , the minimum value is 44 , and the maximum value is 56 . From the analysis of the frequency distribution above, it can be analyzed variable criteria Primary school teacher competencies in Pulau Rimau Sub-district are as follows.

Table 4. Percentage Categories of Elementary School Teacher Competencies in Pulau Rimau

\begin{tabular}{ccccc}
\hline Number & Norm & Frequency & \% & Category \\
\hline 1 & $\geq 54$ & 2 & $7.2 \%$ & Very Good \\
2 & $50 \mathrm{~s} / \mathrm{d}<54$ & 9 & $32,1 \%$ & Good \\
3 & $47 \mathrm{~s} / \mathrm{d}>50$ & 10 & $35,7 \%$ & Enough \\
4 & $44 \mathrm{~s} / \mathrm{d}<47$ & 7 & $25 \%$ & Less \\
5 & $<44$ & 0 & $0 \%$ & Very Less \\
\hline
\end{tabular}


Based on the results of the analysis of the categories above, it can be stated that the competency of teachers with very good categories is 2 or $7.2 \%$, good categories are 9 or $32.1 \%$, quite good categories are 10 or $35.7 \%$, categories are less by 7 or $25 \%$, and the category is very less 0 or $0 \%$. The results of the analysis show that the competency of elementary school teachers in the Pulau Rimau sub-district is included in the quite good category. The percentage of variable categories of elementary school teacher competencies in Pulau Rimau can be seen also in the following figure:

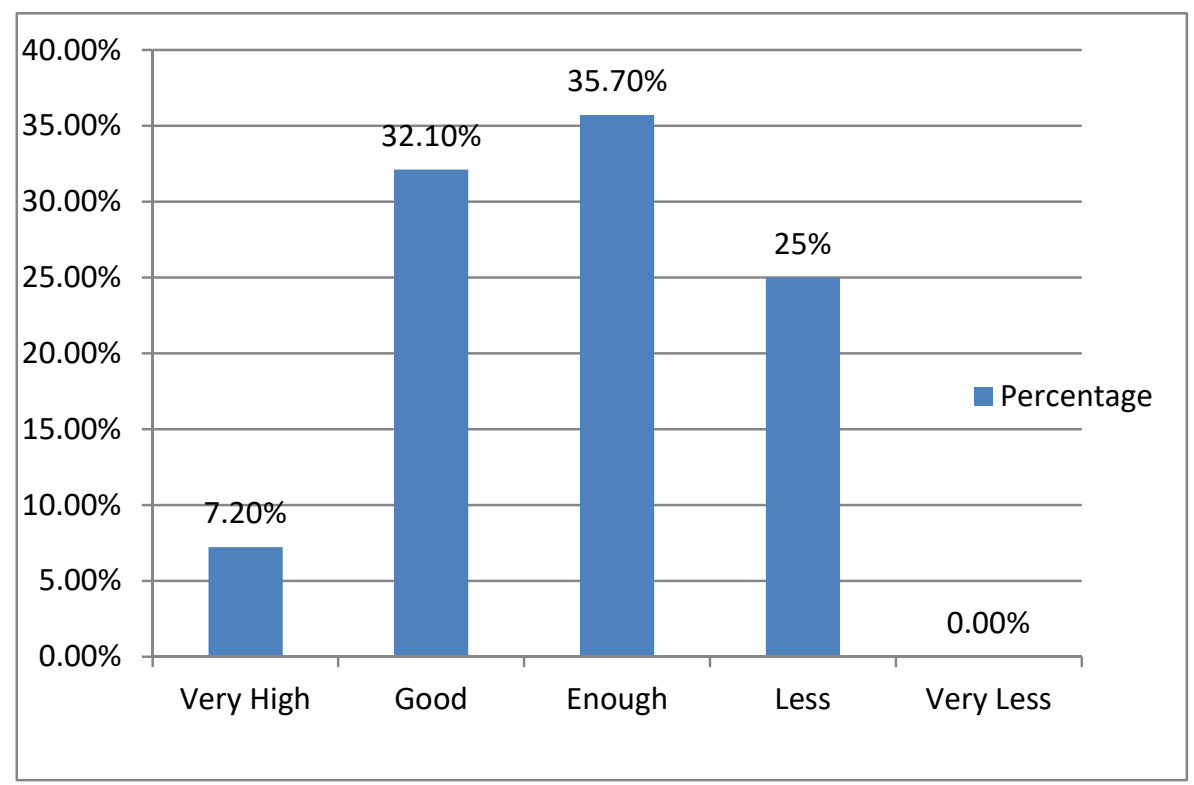

Figure 2: Competency Percentage Categories of Teachers

\section{Primary School Teacher's Certification in Pulau}

Rimau

In this variable, there are 7 indicators to determine primary school teacher certification in Pulau Rimau District, namely 1) Understanding of educational insight; 2) Mastery of academic study material; 3) Understand the characteristics of students; 4) Carry out educational learning; 5) Preparation of RPP; 6) Assessment of student learning achievement; and 7) Implementation of follow-up results of the assessment. All indicators are included in 12 questions. The results of the descriptive analysis of the variables of elementary school teacher competency in Pulau Rimau are as follows.

Table 5. Descriptive Variable of Elementary School Teacher's Certification in Pulau Rimau

\begin{tabular}{lll}
\hline & Teacher's Certification \\
\hline$N$ & Valid & 28 \\
& Missing & 0 \\
Mean & & 60.0698 \\
Median & 60.0000 \\
Std. Deviation & 5.33807 \\
Minimum & 51.00 \\
Maximum & 69.00 \\
\hline
\end{tabular}

Source: Results of Data Processing Using SPSS 
From the results of the frequency distribution analysis above, it can be analyzed the criteria for Elementary School teacher certification variables in the District of Pulau Rimau as follows.

Table 6. Percentage of Elementary School Teacher's Certification in Pulau Rimau

\begin{tabular}{ccccc}
\hline Number & Norm & Frequency & \% & Category \\
\hline 1 & $\geq 68$ & 0 & $0 \%$ & Very Good \\
2 & $63 \mathrm{~s} / \mathrm{d}<68$ & 0 & $0 \%$ & Good \\
3 & $58 \mathrm{~s} / \mathrm{d}>63$ & 0 & $0 \%$ & Enough \\
4 & $52 \mathrm{~s} / \mathrm{d}<58$ & 6 & $21,4 \%$ & Less \\
5 & $<52$ & 22 & $78,6 \%$ & Very Less \\
\hline
\end{tabular}

Source: Results of Data Processing Using SPSS

Based on the results of the analysis of the categories above, it can be pointed out that the certification of teachers with excellent categories is 0 or $0 \%$, good categories are 0 or $0 \%$, quite good categories are 0 or $0 \%$, less categories are 6 or $21.4 \%$, and the category is very less by 22 or $78.6 \%$, the results of the analysis indicate that the certification of
Primary School teachers in the Pulau Rimau is included in the very poor category. In other words, teachers who have been certified still do not meet the certification indicators. The percentage of variable categories of Primary School teacher certification in the Pulau Rimau can also be seen in the following figure.

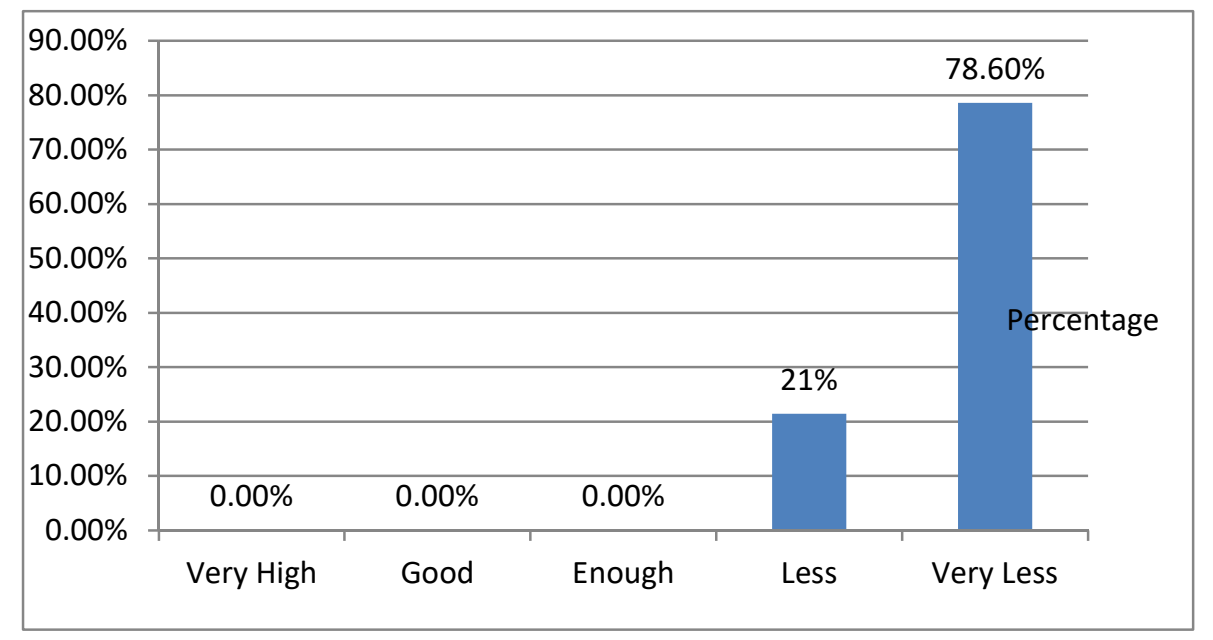

Figure 3. Category Percentage of Teacher Certification Elementary Schools in Pulau Rimau

\section{Elementary School Teacher's Performance in Pulau Rimau}

In this variable, there are 5 indicators to determine the performance of elementary school teachers in Pulau Rimau District, namely: 1) Planning learning; 2) Carry out learning; 3) Assessing learning outcomes; 4) Guiding and training students; 5) Carry out additional tasks. All indicators are included in 13 questions. The results of the descriptive analysis of the performance variables of elementary school teachers in Pulau Rimau are as follows.

Table 7. Descriptive Performance of Elementary School Teachers in Pulau Rimau

\begin{tabular}{ccc}
\hline & & Teacher's Performance \\
\hline$N$ & Valid & 28 \\
& missing & 0 \\
& Mean & 49.0000
\end{tabular}




\begin{tabular}{cc} 
Median & 48.0000 \\
Std. Deviation & 3.37749 \\
Variance & 11.407 \\
Minimum & 44.00 \\
Maximum & 56.00 \\
\hline Source: Results of Data Processing Using SPSS
\end{tabular}

Source: Results of Data Processing Using SPSS

From the results of the frequency distribution analysis above, it can be analyzed criteria for performance variables of elementary school teachers in Pulau Rimau Sub-district as follows.

Table 8. Percentage of Primary School Teacher's Performance in Pulau Rimau

\begin{tabular}{ccccc}
\hline Number & Norm & Frequency & \% & Category \\
\hline 1 & $\geq 54$ & 4 & $14,28 \%$ & Very Good \\
2 & $51 \mathrm{~s} / \mathrm{d}<54$ & 4 & $14,28 \%$ & Good \\
3 & $47 \mathrm{~s} / \mathrm{d}>51$ & 13 & $46,42 \%$ & Enough \\
4 & $44 \mathrm{~s} / \mathrm{d}<47$ & 7 & $25 \%$ & Less \\
5 & $<44$ & 0 & $0 \%$ & Very Less \\
\hline
\end{tabular}

Based on the results of the analysis of the categories above, it can be stated that the performance of teachers in the excellent category is 4 or $14.8 \%$, the good category is 4 or $14.7 \%$, the category is quite good at 13 or $46.42 \%$, the less category is 7 or $25 \%$, and the category is very less at 0 or $0 \%$. The results of the analysis indicate that the performance of elementary school teachers in the Pulau Rimau is included in quite well. Percentage of variable categories of elementary school teacher's performance across Pulau Rimau can also be seen in the following figure:

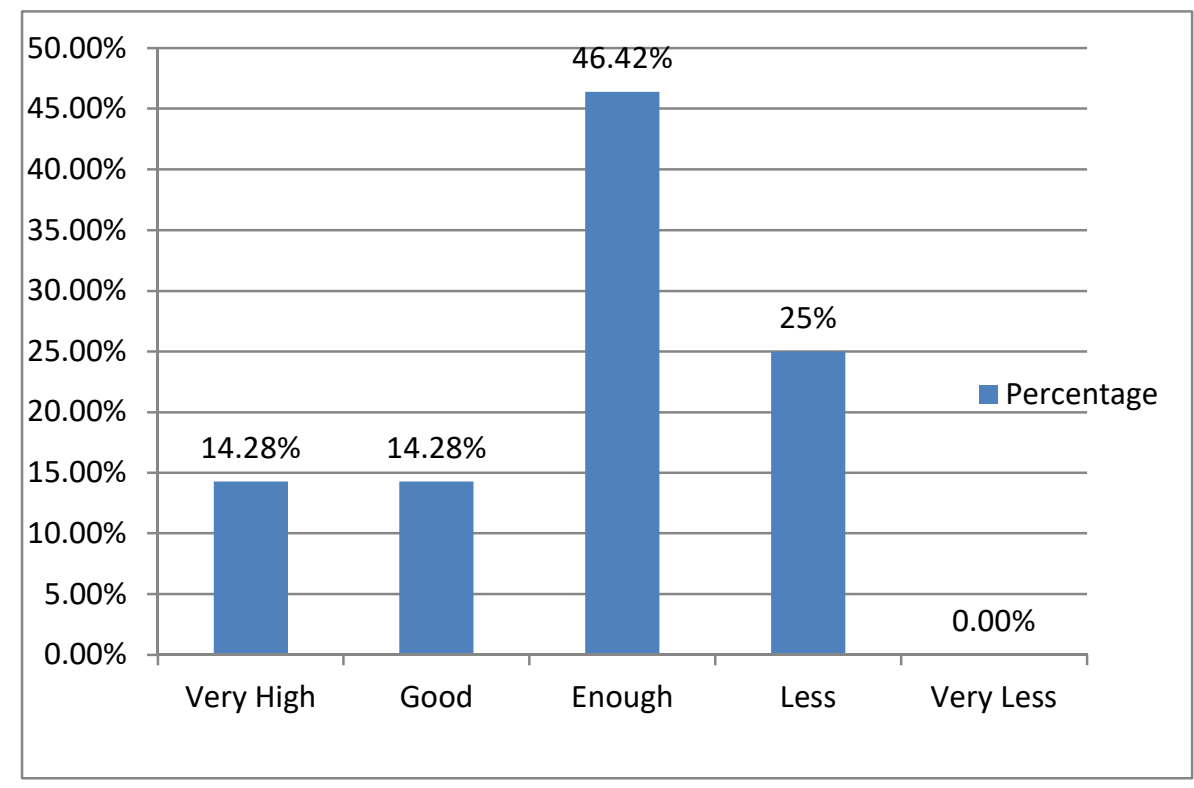

Figure 4. Primary School Teacher's Performance in Pulau Rimau

Based on the results of descriptive statistical analysis obtained a description of the variable teacher's performance with very good categories amounted to 4 or $14.8 \%$, good categories amounted to 4 or $14.7 \%$, quite good categories of 
13 or $46.42 \%$, less categories of 7 or $25 \%$, and the category is very less by 0 or $0 \%$. The results of the analysis indicate that the performance of elementary school teachers in the Pulau Rimau is included in quite well. Then the teacher competency variable obtained results are teacher competency with very good categories amounting to 2 or $7.2 \%$, good categories amounting to 9 or $32.1 \%$, quite good categories of 10 or $35.7 \%$, less categories of 7 or $25 \%$, and the category is very less 0 or $0 \%$. The results of the analysis show that the competency of elementary school teachers in Pulau Rimau is included in both categories.

Then for the teacher certification variable with a very good category of 0 or $0 \%$, a good category of 0 or $0 \%$, a good enough category of 0 or $0 \%$, a category of less than 6 or $21.4 \%$, and a very less category of 22 or $78,6 \%$, the results of the analysis show that elementary school teacher certification in Pulau Rimau is included in the very poor category. For the teacher's performance variable with a very good category 4 or $14.8 \%$, a good category 4 or $14.7 \%$, a pretty good category of 13 or $46.42 \%$, a category of less than 7 or $25 \%$, and a very less category of 0 or $0 \%$. The results of the analysis indicate that teacher's performance of in the Pulau Rimau.

Based on the significance test ( $t$ test) of organizational culture on teacher's performance in Pulau Rimau District, the $\mathrm{t}$-value of $4,584 \leq$ price of $\mathrm{t}$-table is 2.055 where the price of $\mathrm{t}$ is greater than $\mathrm{t}$ table, $\mathrm{H}_{1}$ is rejected, so there is a significant influence between the organizational culture of the head school performance of elementary school teachers in Pulau Rimau. Based on the significance test of competency $\left(\mathrm{X}_{2}\right)$ on teacher's performance $(\mathrm{Y})$ in Pulau Rimau, the value of $t$ value is $11.360 \geq$ the price of $t$-table is 2.055 where the price of $t$ arithmetic is greater than $t$-table then $\mathrm{Ha}_{2}$ is accepted so there is a significant influence between competencies on teacher's performance Pulau Rimau.

From the Anova test above, an F-count is 155,189 was obtained with a significance level of $0,000<$ probability value $\alpha 0.05$ while the F-table corresponds to a significance level of 0.05 (3.24) of 3.01 so that the $\mathrm{F}$ count $>\mathrm{F}$ table $(155,189>3.01)$ so that $\mathrm{Ho}_{3}$ is rejected, meaning that there is a significant influence jointly between organizational culture, competency and teacher's certification on the teacher's performance in Pulau Rimau. Then obtained Rsquare value of 0.886 . This explains that the coefficient is reflected at $88.6 \%$ so it can be concluded that the influence of organizational culture, competency and teacher's certification on the teacher's performance in Pulau Rimau together is $88.6 \%$ and the remaining $11.4 \%$ is influenced by other factors not examined in this study.

\section{Conclusion}

The conclusion of this study showed that 1) there is significant influence of organizational culture on teacher's performance; 2) there is significant influence of competency on the teacher's performance; 3) there is significant influence of teacher's certification on the teacher's performance; 4) there is significant influence jointly organizational culture, competency and teacher's certification on the teacher's performance.

\section{ACKNOWLEDGMENT}

We would like to express our special thanks and gratitude to Rector Universitas PGRI Palembang, Director of Graduate Program and the teachers of Primary School in Pulau Rimau who gave us the support to do this wonderful project. This project was funded independent. Secondly, we would also like to thank our friends in Management of Education who helped us a lot in finalizing this project within the limited time frame.

\section{REFERENCES}

[1] Andriani, S., Kesumawati, N., \& Kristiawan, M. (2018). The Influence of the Transformational Leadership and Work Motivation on Teachers Performance. International Journal of Scientific \& Technology Research, 7(7).

[2] Apriana, D., Kristiawan, M., \& Wardiah, D. (2019). Headmaster's Competency In Preparing Vocational School Students For Entrepreneurship. International Journal of Scientific \& Technology Research, 8(8).

[3] Arikunto,S. (2010). Prosedur Penelitian [Research procedure]. Jakarta: Rineka Cipta.

[4] Chatab, N. (2012). Profil Budaya Organisasi [Organizational Culture Profile]. Bandung: Alfabeta.

[5] Disdikpora. (2017). Laporan Tahunan Kinerja Pegawai Disdikporapar 2017 [Disdikpora 2017 Employee Performance Annual Report]. Banyuasin: Disdikpora Banyuasin

[6] Fathurrochman, I., Budiman, D. A., Alamsyahril, \& Kristiawan, M. (2019). Revitalization Management of Islamic Boarding School Preventing The Radicalism. Restaurant Business, (10), 495-505.

[7] Hamalik, O. (2013). Media Pendidikan [Educational Media]. Bandung: Citra Aditya Bakti. 
[8] Hasibuan, M. S.P. (2012). Manajemen Sumber Daya Manusia [Human Resource Management]. Jakarta : Cetakan 9. PT. Bumi Aksara

[9] Irmayani, H., Wardiah, D., \& Kristiawan, M. (2018). The Strategy of SD Pusri In Improving Educational Quality. International Journal of Scientific \& Technology Research, 7(7).

[10] Jakparudin. (2018). The Effect of Implementation of Teacher Certification on Teacher's performance in Banyuasin District. Thesis. Palembang: Tridinanti University.

[11] Jackson. H.J. (2011). Manajemen Sumber Daya Manusia [Human Resource Management]. Jakarta: Salemba Empat.

[12] Khasanah, U., Kristiawan, M., \& Tobari. (2019). The Implementation of Principals' Academic Supervision In Improving Teachers' Professionalism in the State Primary Schools. International Journal of Scientific \& Technology Research, 8(8).

[13]Lian, B., Kristiawan, M., \& Fitriya, R. (2018). Giving Creativity Room to Students through the Friendly School's Program. International Journal of Scientific \& Technology Research, 7(7).

[14]Locke, E. A., \& Latham, G. P. (2011). A theory of goal setting and task performance. Englewood Cliffs, NJ: Prentice Hall.

[15] Mangkuprawira. (2014). Manajemen Sumber Daya Manusia Strategik [Strategic Human Resource Management]. Jakarta: Ghalia Indonesia.

[16] Musfiqon, H.M. (2012). Metodologi Penelitian Pendidikan Educational Research Methodology]. Jakarta: PT. Prestasi Pustakaraya.

[17]Mulyasa, E. (2010). Menjadi Guru Profesional (Menciptakan Pembelajaran Kreatif dan Menyenangkan) [Become a Professional Teacher (Creating Creative and Enjoyable Learning)]. Bandung: Remaja Rosdakarya

[18] Mulyasa E. (2010). Standar Kompetensi dan Sertifikasi Guru [Teacher Competency Standards and Certification], Bandung: Remaja Rosdakarya.

[19] Murtiningsih, M., Kristiawan, M., \& Lian, B. (2019). The Correlation Between Supervision of Headmaster and Interpersonal Communication With Work Ethos of the Teacher. European Journal of Education Studies.

[20] Park, J.W. (2015). Surimi Gel Colors as Affected by Moisture Content and Physical Conditions. Jurnal Food Science. 60 (1): 15-18.

[21] Minister of National Exception No. 16 of 2007 concerning Organizational Culture Standards and Teacher's competency
[22] Prawirosentono, S. (2011). Kinerja [The performance]. Bandung: Alfabeta.

[23] Robbins S, P. (2012). Perilaku Organisasi [Organizational behavior]. Jakarta: Salemba Empat.

[24] Renata, R., Wardiah, D., \& Kristiawan, M. (2018). The Influence of Headmaster's Supervision and Achievement Motivation on Effective Teachers. International Journal of Scientific \& Technology Research, 7(4).

[25] Salwa., Kristiawan, M., \& Lian, B. (2019). The Effect of Academic Qualification, Work Experience and Work Motivation towards Primary School Principal Performance. International Journal of Scientific \& Technology Research, 8(8).

[26] Saniyah. (2008). Teacher Motivation in Participating in the Teacher Certification Program in Bangkalan Model Madrasah Aliyah Negeri (MAN). Malang State Islamic University: Malang.

[27] Sarina., Kristiawan, M., \& Wardiah, D. (2019). Module Development the Utilization of Patchwork Fabric As Teaching Materials Crafts on the Subjects of Craft and Entrepreneurship For High School Students. International Journal of Scientific \& Technology Research, 8(5).

[28] Sugiyono. (2012). Metode Penelitian Kuantitatif dan R dan D [Quantitative Research Methods and R and D], Bandung: Alfabeta.

[29] National Education System Law No. 20 of 2003 and National Education Standards

[30] Tobari., Kristiawan, M., \& Asvio, N. (2018). The Strategy of Headmaster on Upgrading Educational Quality In Asean Economic Community (AEC) Era. International Journal of Scientific \& Technology Research, 7(4).

[31] Wandasari, Y., Kristiawan, M., \& Arafat, Y. (2019). Policy Evaluation of School's Literacy Movement on Improving Discipline of State High School Students. International Journal of Scientific \& Technology Research, 8(4).

[32] Widoyoko, E, P. (2012). Teknik Penyusunan Instrumen Penelitian [Research Instrument Designing Techniques].Yogyakarta: Pustaka Pelajar 